\title{
PERFORMANCE OF TWO READY-TO-USE SYSTEMS FOR ENUMERATION OF AEROBIC MESOPHILIC MICROORGANISMS IN FROZEN GOAT MILK
}

\author{
Paula Tavolaro; Analí Ramazotti Ferrati; Maria Teresa Destro; Mariza Landgraf; \\ Bernadette Dora Gombossy de Melo Franco*
}

\author{
Departamento de Alimentos e Nutrição Experimental, Faculdade de Ciências Farmacêuticas, Universidade de São Paulo, \\ São Paulo, SP, Brasil
}

Submitted: May 25, 2005; Returned to authors for corrections: September 09, 2005; Approved: September 20, 2005

\begin{abstract}
Enumeration of aerobic microorganisms in Brazilian pasteurized bovine milk using Petrifilm ${ }^{\mathrm{TM}}$ AC and Simplate ${ }^{\mathrm{TM}}$ TPC was shown to be influenced by the nature of autochthonous microbiota. This study was conducted to assess if the same occurs in pasteurized goat milk. Pasteurized frozen goat milk $(n=62)$ was purchased in retail stores in São Paulo, SP, Brazil, and submitted to mesophilic aerobic counts using Petrifilm ${ }^{\mathrm{TM}}$ AC and Simplate ${ }^{\mathrm{TM}}$ TPC, comparing results with those of conventional pour-plates. Correlation indexes above 0.90 were ranked "excellent"; those between 0.80 and 0.89 , "good", those from 0.79 to 0.50 , "fair", and those below 0.50 , "poor". Correlation indexes for Petrifilm ${ }^{\mathrm{TM}}$ AC counts were "good", but "poor" using Simplate ${ }^{\mathrm{TM}}$ TPC. Comparison of Petrifilm $^{\mathrm{TM}}$ AC and Simplate ${ }^{\mathrm{TM}}$ TPC also produced "poor" correlation indexes. Results suggest that autochthonous microbiota have little, if any, influence on the performance of these two systems, since good correlations were achieved using Petrifilm ${ }^{\mathrm{TM}}$ AC.
\end{abstract}

Key words: rapid methods, ready-to-use systems, goat milk, Petrifilm ${ }^{\mathrm{TM}}$ AC, Simplate ${ }^{\mathrm{TM}} \mathrm{TPC}$

\section{INTRODUCTION}

Traditional methods for enumeration of microorganisms in milk and other food products demand too much material, time and hands-on work and results become available only after two or three days (31). In the past few years, several alternative analytical methods have been developed aiming the production of faster results and simplification of the analytical procedure. Among them, the ready-to-use systems are the most popular, mainly because they eliminate culture media preparation and labware sterilization $(5,7,21)$. Petrifilm ${ }^{\mathrm{TM}}$ plates $(3 \mathrm{M}$ Microbiology, St. Paul, MN, USA) and SimPlate ${ }^{\mathrm{TM}}$ plates (Biocontrol Systems, Inc, Bellevue, WA, USA) are two successful ready-to-use systems, with increasing acceptance in the food microbiology laboratories because of their convenience, ease-to-use, accuracy, acceptable cost-benefit relationship and validation by the recognized international regulatory bodies, like the AOAC.
Results of international validations of analytical methods should be interpreted with care, because they do not take into account regional variations in the microbial ecology of foods. In Brazil, it was demonstrated that the autochthonous microflora of pasteurized bovine milk produced in certain regions influenced significantly the performance of these two ready-touse systems for enumeration of aerobic microorganisms (2). The counts of aerobes using Petrifilm ${ }^{\mathrm{TM}}$ AC or Simplate ${ }^{\mathrm{TM}} \mathrm{TPC}$ plates were lower than those yielded by the standard plating count method. In a previous study, these authors reported that Brazilian pasteurized milk contain a high number of thermoduric Gram positive cocci, unable to reduce TTC of the Petrifilm ${ }^{\mathrm{TM}}$ plates or to produce fluorescence when tested in Simplate ${ }^{\mathrm{TM}}$ TPC (1). These are indications that the microbial ecology of pasteurized milk may have an important role in the performance of these ready-to-use systems.

Another important aspect related to the performance of these ready-to-use counting systems is that stressed microorganisms

*Corresponding Author. Mailing address: Departamento de Alimentos e Nutrição Experimental, FCF - USP. Av. Prof. Lineu Prestes, 580, Bloco 13B, Cidade Unviersitária. 05508-900, São Paulo, SP, Brasil. E-mail: bfranco@usp.br 
may not grow well. Several factors, mainly acidic $\mathrm{pH}$, low Aw, and presence of preservatives, encountered in many food matrices, may induce metabolic stress, and interfere with the enzymatic reactions on which positive results of these systems are based. Food debris, presence of certain components, like lipids and salts, and the color of the food product may also influence negatively the performance of these systems.

Goat milk has an increasing market in Brazil. Daily goat milk production in Brazil is 22,000 liters, and it is traded as fluid milk (93\%), powdered milk (4\%) and cheese, yogurt and sweet products $(3 \%)(8)$. Fluid milk may be sold as ultra-high temperature treated or pasteurized and frozen, the object of the present study. In relation to the microbiological quality of pasteurized frozen goat milk produced in Brazil, very little information is available. The Brazilian Ministry of Agriculture (6) established the following parameters for pasteurized and ultrahigh temperature treated goat milk: Raw milk - standard plate count maximum 500,000 CFU/mL. Pasteurized milk standard plate count maximum $50,000 \mathrm{CFU} / \mathrm{mL}$, coliforms $\left(30^{\circ} \mathrm{C}\right)$ maximum $1 \mathrm{CFU} / \mathrm{mL}$; coliforms $\left(45^{\circ} \mathrm{C}\right)$ maximum $1 \mathrm{CFU} / \mathrm{mL}$; coagulase positive Staphylococcus spp. absence in $25 \mathrm{~mL}$; Salmonella, absence in $25 \mathrm{~mL}$.

In the analysis of five brands of pasteurized milk sold in northeast Brazil, three were found to be inside the range of microbiological quality recommended by the Brazilian Ministry of Agriculture (25). In southeast Brazil, the analysis of 30 samples of pasteurized frozen goat milk, showed only one above the standard determined by legal regulations in relation to mesophilic aerobic counts (20).

No information is available about the interference of the natural microbiota of other types of milk produced in Brazil besides bovine milk, on the performance of these ready-to-use systems. The influence of freezing on the viable cell counts is also unknown. Thus, this study aimed at the comparison of mesophilic and psychrotrophic microorganism counts in pasteurized frozen goat milk, purchased at retail stores in Brazil, using the conventional pour plating procedure as the standard for comparison.

\section{MATERIALS AND METHODS}

Sixty-two samples of pasteurized frozen goat milk were purchased in supermarkets in São Paulo, SP, Brazil. In the laboratory, they were thawed under refrigeration (mean temperature: $7.8^{\circ} \mathrm{C}$ ). Packages were homogenized by manual shaking, disinfected with $70 \%$ alcohol, punctured with sterile scissors and $10 \mathrm{~mL}$ of the content were transferred to a sterile flask. These samples were submitted to decimal dilutions up to $1: 1.000$ in sterile phosphate dilution water $(14,17)$.

One $\mathrm{mL}$ of each dilution was placed in four Petrifilm ${ }^{\mathrm{TM}} \mathrm{AC}$ (3M Microbiology. St. Paul, MN, USA) plates, following the manufacturer instructions. Two plates were incubated at $30 \pm$ $1^{\circ} \mathrm{C}$ for $48 \pm 3 \mathrm{~h}$ for aerobic mesophilic microorganism counts, and two at $7 \pm 1^{\circ} \mathrm{C}$ for 10 days for psychrotrophic microorganism counts. Plates presenting 25 to 250 red colonies were selected and counted and the number of $\mathrm{CFU} / \mathrm{mL}$ was determined, considering the average of the duplicates.

SimPlate ${ }^{\mathrm{TM}}$ TPC (Biocontrol Systems, Inc, Bellevue, WA, USA) plates were inoculated according to the procedure described by the manufacturer. Milk dilutions were used to rehydrate the culture medium, which was poured onto the plates. For aerobic mesophilic microorganism counts, two plates were prepared and incubated at $30^{\circ} \mathrm{C}$ for 24 hours. Additionally, two plates were prepared and incubated at $7 \pm 1^{\circ} \mathrm{C}$ for 10 days, for psychrotrophic microorganism counts. After incubation, the number of fluorescent wells was counted under UV light and the MPN mL ${ }^{-1}$ was calculated using the MPN table supplied by the manufacturer.

Duplicates of each dilution $(1 \mathrm{~mL})$ were pour-plated in Standard Methods Agar (Oxoid Ltd., Basingstoke, Hampshire, England) and incubated at $30 \pm 1^{\circ} \mathrm{C}$ for $48 \pm 3 \mathrm{~h}$ for counts of aerobic mesophilic microorganisms. Two additional plates for each dilution were prepared and incubated at $7 \pm 1^{\circ} \mathrm{C}$ for 10 days for psychrotrophic microorganism counts. Plates presenting 25 to 250 colonies were selected and counted and the number of CFU/mL was determined (14).

Values obtained in the counts were transformed to decimal logs, and the Correlation Coefficient, Slope and Intercept for the results obtained by the three methods were calculated, using linear regression methods ( $\mathrm{p} \leq 0.05$ ), in MS Excel 7.0 (Microsoft Inc., USA). Correlations were ranked as "Excellent", "Good", "Fair" or "Poor" according to the values of the correlation indexes, as shown in Table 1. The correlation index was determined by the most common rank obtained in the three categories (correlation coefficient, slope and intercept).

\section{RESULTS AND DISCUSSION}

Since their launch in 1984, Petrifilm ${ }^{\mathrm{TM}}$ plates have been extensively tested and compared with several other counting methods, including the conventional pour plate method, and the results of these comparisons lead to the conclusion that Petrifilm $^{\mathrm{TM}}$ AC plates are an excellent alternative to the conventional procedure for enumeration of microorganisms in foods, including milk and dairy products $(4,5,7,9,10,12$, $13,16,18,19,24)$. Simplate ${ }^{\mathrm{TM}}$ plates have also been submitted to

Table 1. Ranking of results according to the correlation indexes.

\begin{tabular}{lcccc}
\hline Index & Excellent & Good & Fair & Poor \\
\hline Correlation coefficient & $1.00-0.90$ & $0.89-0.80$ & $0.79-0.50$ & $<0.50$ \\
Slope & $1.00-0.90$ & $0.89-0.80$ & $0.79-0.50$ & $<0.50$ \\
Intercept & $0.00-0.10$ & $0.11-0.20$ & $0.20-0.50$ & $>0.50$ \\
\hline
\end{tabular}


equivalence studies and good correlation indexes were also reported $(3,11,15,22,29,30)$.

The correlation indexes found for Petrifilm ${ }^{\mathrm{TM}} \mathrm{AC}$ plates for the enumeration of mesophilic microorganisms in pasteurized frozen goat milk, compared with the conventional pour-plate method, and the correlations observed in other studies in the literature are presented in Table 2; those for Simplate ${ }^{\mathrm{TM}} \mathrm{TPC}$ and pour plates, in Table 3, and those for Petrifilm ${ }^{\mathrm{TM}} \mathrm{AC}$ and Simplate ${ }^{\mathrm{TM}}$ TPC, in Table 4.

The correlation parameters for aerobic mesophilic microorganism counts obtained with Petrifilm ${ }^{\mathrm{TM}} \mathrm{AC}$ and the conventional pour-plate method were: Correlation Coefficient 0.7860, Slope, 0.8674 and Intercept, 0.090. According to the criteria for results ranking, this correlation was ranked as "good". These values were similar to those reported earlier $(2,16)$, but these studies presented further findings in relation to the method. In the analysis of pasteurized milk and yogurt ice-cream, it was observed that Petrifilm ${ }^{\mathrm{TM}}$ plates produced higher counts than pour-plates (16). Another study showed that correlation between counts obtained by the two procedures depended on the microbiological quality of pasteurized milk, i.e., the highest the background flora the less effective was the Petrifilm ${ }^{\mathrm{TM}} \mathrm{AC}$ plate (2). Correlation Coefficient obtained by these authors in Brazil decreased together with the quality of milk. There are reports on lower correlations in the analysis of pasteurized bovine milk (24), and of "excellent" correlations $(4,13)$ with raw milk and several kinds of foods $(7,18)$.

In relation to SimPlate ${ }^{\mathrm{TM}}$ plates, correlation indexes detected for pasteurized frozen goat milk were: Correlation Coefficient 0.3198; Slope, 0.2936 and Intercept, 2.150, ranked as "poor". Despite the good performance of Simplate ${ }^{\mathrm{TM}} \mathrm{TPC}$ plates reported in other studies, the present study confirmed previous results reported in Brazil (2) for pasteurized bovine milk. These authors showed that, as occurred with Petrifilm ${ }^{\mathrm{TM}}$ plates, the decrease in microbiological quality of milk led to a decrease in the performance of Simplate ${ }^{\mathrm{TM}}$ TPC. Other authors reported correlation indexes ranked "excellent" (29) and "fair" (26), in the analysis of several kinds of foods, "excellent" (15) in the analysis of water, and "good" in the analysis of ice cream, using Simplate TPC-CI. This method was also studied by another group of researchers in a collaborative study with different kinds of foods (11). They did not present correlation coefficients, but and showed that differences observed between Simplates ${ }^{\mathrm{TM}}$ and the reference pour-plates were less than 0.3 mean log count. However, the analysis of mold and yeast in foods (28) Simplate ä did not present correlation indexes as high as those reported by the first studies on the method $(3,29,30)$, while Petrifilm ${ }^{\mathrm{TM}}$ produced "excellent" correlations.

Table 2. Results found in the literature and those of the present study in relation to the comparison of Petrifilm ${ }^{\mathrm{TM}} \mathrm{AC}$ and conventional pour plates.

\begin{tabular}{|c|c|c|c|c|}
\hline Reference (\# in the text) & $\begin{array}{l}\text { Correlation coeffient } \\
(C C) \text {. slope }(S) \\
\text { and intercept }(I)\end{array}$ & Ranking & Type of food & Notes \\
\hline Present study for mesophiles & $\begin{array}{l}C C 0.8860 \\
S 0.8674 \\
I 0.090\end{array}$ & Good & Frozen, pasteurized goat milk & \\
\hline Present study for psychrotrophs & $\begin{array}{l}C C 0.7480 \\
S 0.8241 \\
I 0.193\end{array}$ & Fair & Frozen, pasteurized goat milk & \\
\hline Senyk et al., 1987 (24) & $\begin{array}{l}C C 0.78 \\
S 0.56 \\
I 0.79\end{array}$ & Fair & Pasteurized fluid milk & \\
\hline Bishop and Juan, 1988 (4) & $\begin{array}{l}I 0.117 \\
S 1.002 \\
I 0.117\end{array}$ & Excellent & Raw milk & \\
\hline Chain and Fung, 1991 (7) & СC 0.999 & Excellent & Different types of foods & \\
\hline Jordano et al., 1995 (16) & СС 0.897 & Good & $\begin{array}{l}\text { Pasteurized milk; } \\
\text { yoghurt ice cream }\end{array}$ & \\
\hline Mizuochi and Kodaka, 2000 (18) & СС 0.97 & Excellent & Different types of foods & \\
\hline Taniwaki et al., 2001 (28) & СС 0.9299 & Excellent & & Mold and yeast count \\
\hline Beloti et al., 2002 (2) & СС 0.878 & Good & Pasteurized bovine milk & \\
\hline Hayes et al., 2003 (13) & СС 0.94 & Excellent & Bovine raw milk & \\
\hline
\end{tabular}


Tavolaro et al.

Table 3. Results found in the literature and those of the present study in relation to the comparison of Simplate ${ }^{\mathrm{TM}} \mathrm{TPC}$ and conventional pour plates.

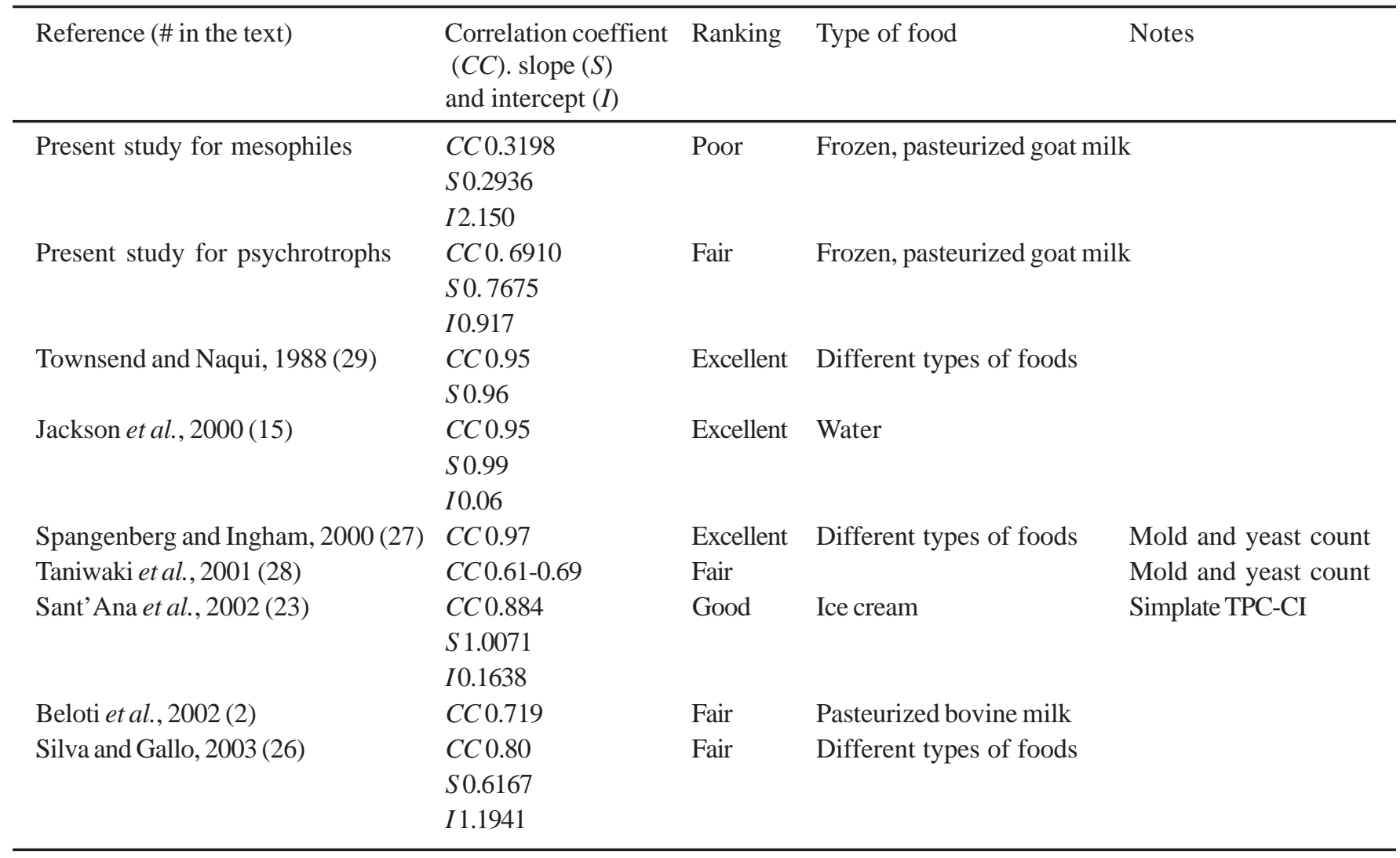

Table 4. Results found in the literature and those of the present study in relation to the comparison of Petrifilm ${ }^{\mathrm{TM}} \mathrm{AC}$ and Simplate ${ }^{\mathrm{TM}}$ TPC.

\begin{tabular}{|c|c|c|c|c|}
\hline Reference (\# in the text) & $\begin{array}{l}\text { Correlation coeffient } \\
(C C) \text {. slope }(S) \\
\text { and intercept }(I)\end{array}$ & Ranking & Type of food & Notes \\
\hline Present study fort mesophiles & $\begin{array}{l}C C 0.4846 \\
S 0.4166 \\
I 1.960\end{array}$ & Poor & Frozen. pasteurized goat milk & \\
\hline Present study for psychrotrophs & $\begin{array}{l}C C 0.5968 \\
S 0.5977 \\
I 1.582\end{array}$ & Fair & Frozen, pasteurized goat milk & \\
\hline Townsend et al., no date (30) & $\begin{array}{l}C C 0.97 \\
S 0.99 \\
\text { I } 0.11\end{array}$ & Excellent & & \\
\hline Russel, 2000 (22) & CC 0.91-0.95 & Excellent & $\begin{array}{l}\text { Poultry carcasses } \\
\text { and ground beef }\end{array}$ & Coliform counts \\
\hline Sant'Ana et al., 2002 (23) & $\begin{array}{l}C C 0.886 \\
S 0.9865 \\
I 0.1501\end{array}$ & Good & Ice cream & Simplate TPC-CI \\
\hline
\end{tabular}


When results obtained in Petrifilm ${ }^{\mathrm{TM}} \mathrm{AC}$ and in SimPlate ${ }^{\mathrm{TM}}$ TPC were compared, the Correlation Coefficient was 0.4826; Slope, 0.4166; Intercept, 1.960, ranked "poor". In a similar study (30) values for these parameters were "excellent", what was also reported when the two methods were used in coliform counts (22) in the analysis of poultry carcasses and ground beef.

In the present study, the correlation indexes were lower than in other reports, mainly in relation to Simplate ${ }^{\mathrm{TM}}$. The performance of both methods may have been affected by freezing of the milk. However, the comparison of Simplate ${ }^{\mathrm{TM}}$ TPC-CI and conventional methods in the analysis of ice-cream in Brazil showed that the two systems were similar (23). In the comparison between SimPlate ${ }^{\mathrm{TM}}$ TPC-CI and Petrifilm ${ }^{\mathrm{TM}}$ AC, correlation indexes were ranked "good". Although there is reference to the analysis of frozen products in the initial study of SimPlate ${ }^{\mathrm{TM}}$ (30), the correlation found for this kind of product was not presented. In another study with frozen hamburger patties and frozen fruits individual correlation coefficients were not presented, either (11). It is important to perform further studies using frozen products, in order to verify if this method of food preservation may influence the results of enzymatic tests, such as SimPlate ${ }^{\mathrm{TM}}$.

\section{ACKNOWLEDGEMENTS}

The authors are grateful to Fundação de Amparo à Pesquisa do Estado de São Paulo (FAPESP) for providing the funds for this study (Process 98/04365-1) and to Conselho Nacional de Pesquisa (CNPq) for the graduate fellowship to author PT.

\section{RESUMO}

\section{Desempenho de dois sistemas prontos para uso na enumeração de microrganismos aeróbios mesófilos em leite de cabra congelado}

Foi demonstrado que a enumeração de microrganismos aeróbios em leite bovino brasileiro pasteurizado utilizando-se as placas Petrifilm ${ }^{\mathrm{TM}}$ AC e Simplate ${ }^{\mathrm{TM}}$ TPC pode ser influenciada pela microbiota autóctone. O presente estudo foi conduzido para se determinar se o mesmo ocorreria com leite de cabra pasteurizado. Foram analisadas 62 amostras de leite pasteurizado e congelado, vendidas no comércio varejista de São Paulo, SP. As amostras foram submetidas à contagem de microrganismos aeróbios mesófilos utilizando-se placas Petrifilm ${ }^{\mathrm{TM}} \mathrm{AC}$ e Simplate ${ }^{\mathrm{TM}}$ TPC, comparando-se os resultados com a semeadura em profundidade. Um índice de correlação acima de 0,90 foi classificado como "excelente", entre 0,80 e 0,89 como "bom", entre 0,79 e 0,50 como "fraco", e abaixo de 0,50 , como "ruim". O índice de correlação para as contagens em placas Petrifilm ${ }^{\mathrm{TM}}$ $\mathrm{AC}$ foi "bom", mas foi "ruim" quando se usou as placas
Simplate ${ }^{\mathrm{TM}}$ TPC. A comparação entre os resultados obtidos com as placas Petrifilm ${ }^{\mathrm{TM}} \mathrm{AC}$ e Simplate ${ }^{\mathrm{TM}} \mathrm{TPC}$ também produziu um índice de correlação "ruim". Os resultados sugerem que a microbiota autóctone têm pouca ou nenhuma influência sobre a performance destes dois sistemas, pois boas correlações foram obtidas com o uso das placas Petrifilm ${ }^{\mathrm{TM}}$ AC.

Palavras-chave: métodos rápidos, sistemas prontos para uso, leite de cabra, Petrifilm ${ }^{\mathrm{TM}}$ AC, Simplate ${ }^{\mathrm{TM}} \mathrm{TPC}$

\section{REFERENCES}

1. Beloti, V.; Barros, M.A.F.; Freitas, J.C.; Nero, L.A.; Souza, J.A.; Santana, E.H.W.; Franco, B.D.G.M. Frequency of 2,3,5triphenyltetrazolium (TTC) non-reducing bacteria in pasteurized milk. Rev. Microbiol., 30, 137-140, 1999.

2. Beloti, V.; Barros, M.A.F.; Nero, L.A.; Pachemshy, J.A.S.; Santana, E.H.W.; Franco, B.D.G.M. Quality of pasteurized milk influences the performance of ready-to-use systems for enumeration of aerobic microorganisms. Int. Dairy J., 12, 413-418, 2002.

3. Beuchat, L.R.; Copeland, F.; Curiale, M.S.; Danisavitch T.; Gangar, V.; King, B. W.; Lawlis, T.S.; Lokin, R.O.; Okwuso, A.J.; Smith, C.F.; Townsend, D.E. Comparison of the SimPlate ${ }^{\mathrm{TM}}$ total plate count method with Petrifilm ${ }^{\mathrm{TM}}$; Redigel ${ }^{\mathrm{TM}}$ and conventional pour plate methods for enumerating aerobic microorganisms in foods. J. Food Prot., 61(1), 14-18, 1998.

4. Bishop, J.R.; Juan, J.Y. Improved methods for quality assessment of raw milk. J. Food Prot., 51(12), 955-957, 1988.

5. Blackburn, C.W.; Baylis, C.L.; Petitt, S.B. Evaluation of Petrifilm methods for enumeration of aerobic flora and coliforms in a wide range of foods. Lett. Appl. Microbiol., 22(2), 137-140, 1996 (Abstract)

6. Brazil, Ministério da Agricultura e Pecuária, 1999. Portaria número 56, de 07/12/99. Anexo VI: Regulamento técnico de produção identidade e qualidade do leite de cabra. Diário Oficial da União. Seção I. Brasília, 234, p. 42-44.

7. Chain, V.S.; Fung, D.Y.C. Comparison of Redigel, Petrifilm, Spiral Plate System, Isogrid, and Aerobic Plate Count for determining the numbers of aerobic bacteria in selected food. J. Food Prot., 54(3), 208-211, 1991

8. Costa, A.L. Leite caprino: um novo enfoque de pesquisa.. http:// www.cnpc.embrapa.br/artigo4.htm, 04/02/04, 2004

9. Curiale, M.S.; Fahey, P.; Fox, T.L.; McAlister, J.S. Dry rehydratable films for enumeration of coliforms and aerobic bacteria in dairy products: collaborative study. J. Assoc. Off. Anal. Chem., 72(2), 312-318, 1989.

10. Ellis, P.; Meldrum, R. Comparison of the compact dry TC and $3 \mathrm{M}$ Petrifilm ACP dry sheet media methods with the spiral plate method for the examination of randomly selected foods for obtaining aerobic colony counts. J. Food Prot., 65(2), 423-5, 2002.

11. Feldsine, P.T.; Leung, S.C.; Lienau, A.H.; Mui, L.A.; Townsend, D.E. Enumeration of total aerobic microorganisms in foods by SimPlate Total Plate Count-Color Indicator methods and conventional culture methods: collaborative study. J. AOAC Int., 86(2), 257-74, 2003.

12. Ginn, R.E.; Packard, V.S.; Fox, T.L. Enumeration of total bacteria and coliforms in milk by dry rehydratable film methods: collaborative study. J. Assoc. Off. Anal. Chem., 69(3), 527-531, 1986.

13. Hayes, M.C.; Ralyea, R.D.; Murphy, S.C.; Carey, N.R.; Scarlett, J.M.; Boor, K.J. Identification and characterization of elevated microbial counts in bulk tank raw milk. J. Dairy Sci., 84(1), 292-8, 2001.

14. Houghtby, G.A.; Maturin, L.J.; Koenig, E.K. Microbiological count methods. In: Marshall, R.T. (ed). Standard methods for examination 
of dairy products. American Public Health Association, Washington: 1992, p.213-246.

15. Jackson, R.W.; Osborne, K.; Barnes, G.; Jolliff, C.; Zamani, D.; Roll, B.; Stillings, A.; Herzog, D.; Cannon, S.; Loveland, S. Multiregional evaluation of the SimPlate heterotrophic plate count method compared to the standard plate count agar pour plate method in water. Appl. Environ. Microbiol., 66(1), 453-4, 2000.

16. Jordano, R.; Lopez, C.; Rodriguez, V.; Cordoba, G.; Medina, L.M.; Barrios, J. Comparison of Petrifilm method to conventional methods for enumerating aerobic bacteria, coliforms, Escherichia coli, yeast and molds in foods. Acta. Microb. Immunol. Hung., 42(3), 255259, 1995.

17. Marshall, R.T. Media. In: Marshall, R.T. (ed). Standard methods for examination of dairy products. American Public Health Association, Washington: 1992, p.85-101.

18. Mizuochi S.; Kodaka H. Evaluation of dry sheet medium culture plate (Compactdry TC) method for determining numbers of bacteria in food samples. J. Food Prot., 63(5), 665-7, 2000.

19. Park, Y.H.; Seo, K.S.; Ahn, J.S.; Yoo, H.S.; Kim, S.P. Evaluation of the Petrifilm plate method for the enumeration of aerobic microorganisms and coliforms in retailed meat samples. J. Food Prot., 64(11), 1841-3, 2001.

20. Pereira, V.G.; Rudge, A.C.; Meira, D.R. Avaliação da qualidade microbiológica e físico-química de leite de cabra comercializado na região centro-oeste do Estado de São Paulo. Higiene Alimentar, 13(61): 65-66, 1999 (Abstract).

21. Piton, C.; Grappin, R. A model for statistical evaluation of precision parameters of microbiological methods: application to dry rehydratable film methods and IDF reference methods for enumeration of total aerobic mesophilic flora and coliforms in raw milk. J. Assoc. Off. Anal. Chem., 74(1), 92-103, 1990.

22. Russell S.M. Comparison of the traditional three-tube most probable number method with the Petrifilm, SimPlate, BioSys optical, and
Bactometer conductance methods for enumerating Escherichia coli from chicken carcasses and ground beef. J. Food Prot., 63(9), 117983, 2000.

23. Sant'Ana, A.S.; Conceição, C.; Azerelo, D.R.P. Comparação entre os métodos rápidos Simplateâ TPC-CI e Petrifilmâ AC e os métodos convencionais de contagem em placas para a enumeração de aeróbios mesófilos em sorvetes. Higiene Alimentar, 16(95), 82-87, 2002.

24. Senyk, G.F.; Kozlowski, S.M.; Noar, P.S.; Shipe, W.F.; Bandler, D.K. Comparison of dry culture medium and conventional plating techniques for enumeration of bacteria in pasteurized fluid milk. $J$. Dairy. Sci., 70(6), 1152-1158, 1987.

25. Silva, E.F.; Lima, V.L.A.G.; Salgueiro, A.A. Avaliação microbiológica do leite de cabra pasteurizado e comercializado na cidade de Recife PE. Higiene Alimentar, 13(66-67), 71-76, 1999.

26. Silva, M.C.; Gallo, C.R. Avaliação da qualidade microbiológica de alimentos com a utilização de metodologias convencionais e do sistema Simplate. Higiene Alimentar, 17(107), 75-85, 2003.

27. Spangenberg, D.S.; Ingham, S.C. Comparison of methods for the enumeration of yeasts and molds in shredded low-moisture, part skim Mozzarella cheese. J. Food Prot., 63(4), 529-533, 2000.

28. Taniwaki, M.H.; Silva, N.; Banhe, A.A.; Iamanaka, B.T. Comparison of culture media, Simplate, and Petrifilm for the enumeration of yeasts and molds in food. J. Food Prot., 64(10), 1592-1596, 2001.

29. Townsend, D.E.; Naqui, A. Comparison of SimPlate Total Plate Count test with plate count agar method for detection and quantitation of bacteria in food. J. AOAC Int., 81(3), 563-9, 1998.

30. Townsend, D.E.; Smith, K.; Naqui, A. A new medium designed to detect and quantify the total viable count of food after only 24 hours of incubation. Bulletin, IDEXX Laboratories. No date, 6p.

31. Vasavada, P.C.; White, C.H. Developing methodology for microbiological evaluation of milk and dairy products - an introduction. J. Dairy Sci., 76, 3099-3100, 1993. 